\title{
Исследование когерентных характеристик суперконтинуума в высоконелинейных волокнах
}

\author{
В.А. Петров $^{1^{*}}$, И.И. Корель ${ }^{1}$, Г.В. Купцов ${ }^{2}$ \\ ${ }^{1}$ Новосибирский государственный технический университет \\ ${ }^{2}$ Новосибирский государственный университет \\ *E-mail:petrov.nstu@gmail.com
}

DOI:10.31868/RFL2018.84-85

Источникам фемтосекундного лазерного излучения находят все более широкое применение в различных областях науки, таких как фемтохимия и медицина, а также с их помощью решается ряд прикладных задач, к одной из которых относится создание стандартов частоты. Особенно важным для данной задачи является стабильность временных и частотных параметров излучения, их когерентные свойства.

В данной работе исследуются когерентные характеристики суперконтинуума в высоконелинейных волокнах. Эволюция прохождения последовательности спектрально ограниченных импульсов в высоконелинейном волокне выполнена согласно модели, представленной в [1]. Моделирование проводилось для импульсов с центральной длины волны в области 1 мкм, шириной спектра $\sim 10$ нм, длительность спектрально ограниченных импульсов 150 фс, пиковая мощность до 1 Вт. Изменение спектра выходных импульсов в зависимости от длины волокна наблюдалось аналогичное результатам моделирования [2].
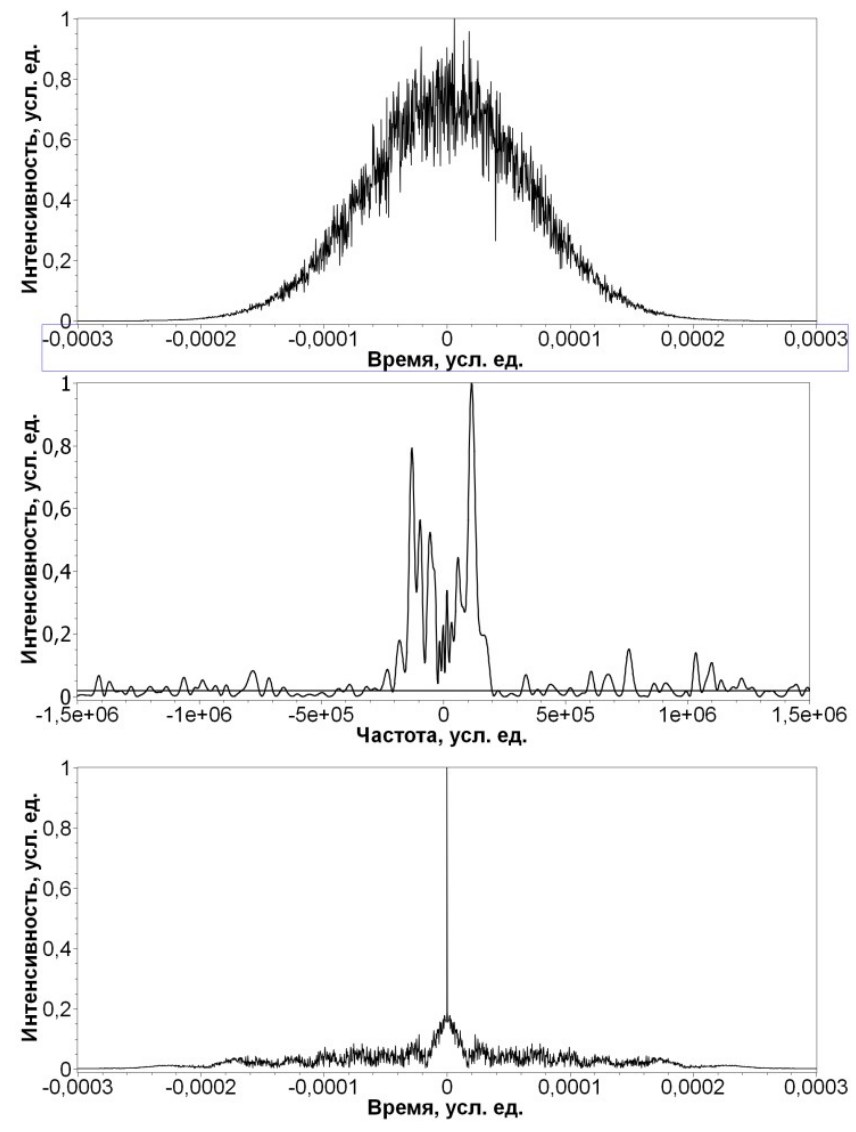

Рисунок 1. Временной профиль (верхний рисунок), спектр (средний рисунок) и автокорреляционная функция (нижний рисунок) усредненного по цугу импульса 
Существует ряд экспериментальных методик оценки когерентных свойств цуга импульсов, например, метод взаимной корреляции частотно-разрешенного оптического стробирования (XFROG) [3]. В качестве критерия оценки когерентности цуга импульсов использовалась модель, представленная в [3]. При этом показано, что уровень нестабильности амплитуды в цуге импульсов на уровне $\sim-10$ дБ существенно не влияет на когерентность всего цуга. Кроме того, предложена модель оценки когерентности спектральных компонент импульса на основе автокорреляционной функции второго порядка (Рис.1).

В случае появление несфазированных компонент в максимуме автокорреляционной функции наблюдается дополнительный максимум, пропорциональный количеству этих компонент. Произведя фильтрацию несфазированных компонент в спектре можно существенно уменьшить амплитуду дополнительного пика в максимуме автокорреляционной функции, таким образом, получая оценку когерентности импульса. С помощью предложенного критерия оценки когерентности суперконтинуума определяется оптимальная длина высоконелинейного волокна.

\section{Литература}

[1] G. P. Agrawal, Fiber-Optic Communication Systems, 4th ed. (Wiley, 2010).

[2] J. M. Dudley et al, IEEE J. Sel. Topics Quantum Electron. 8, 651 (2002).

[3] M. Narhi et al, PHYSICAL REVIEW LETTERS 116, 243901 (2016) 